urn:1sid:zoobank.org:pub:CD4009AE-6DB7-49C9-B4FC-B823E8BF5772

\title{
Phylogenetic Relationships of the Genus Homatula (Cypriniformes: Nemacheilidae), with Special Reference to the Biogeographic History around the Yunnan-Guizhou Plateau
}

\author{
RUI MIN ${ }^{1}$, XIAO-YONG CHEN ${ }^{1, *}$, JUN-XING YANG ${ }^{1, *}$, RICHARD WINTERBOTTOM ${ }^{2}$ \\ \& RICHARD L. MAYDEN ${ }^{3}$ \\ ${ }^{I}$ State Key Laboratory of Genetic Resources and Evolution, Kunming Institute of Zoology, Chinese Academy of Sciences, Kunming, China \\ ${ }_{2}^{2}$ Department of Natural History, Royal Ontario Museum, 100 Queen's Park, Toronto, Ontario, Canada M5S 2C6 \\ ${ }^{3}$ Department of Biology, 3507 Laclede Ave, Saint Louis University, St. Louis, Missouri 63103 \\ *Corresponding authors. Current address: Kunming Institute of Zoology, Chinese Academy of Sciences, 32 Jiao Chang Dong Road, \\ Kunming, Yunnan, China \\ E-mail: chenxy@mail.kiz.ac.cn, yangjx@mail.kiz.ac.cn.
}

\begin{abstract}
Species of the nemacheilid genus Homatula are endemic to the Yunnan-Guizhou Plateau of China. Herein we provide phylogenetic inferences of species relationships based on complete sequences of the mitochondrial cytochrome b gene (cyt $b$ ) and partial sequences of the nuclear recombination activation gene (RAG 1). Both gene trees (and the concatenated data set) support the recognition of five clades in the genus. These analyses also support the hypothesis that two of the lineages resolved represent undescribed species awaiting formal description, and, further, that two previously recognized species are junior synonyms; both are genetically indistinguishable from other previously recognized species. Divergence times of the major clades in Homatula are inferred to be Late Pliocene and the Early Pleistocene, and are correlated with the massive geological events associated with the uplift of the Qinghai-Tibetan Plateau occurring at these times. The reconstruction of drainage histories suggests that the fish faunas of the $\mathrm{Nu}$ and Lancang rivers are basal relative to other riverine faunas in the region, and that the Nanpan and the Jinsha rivers share a more recent history than with any other river systems included in our study.
\end{abstract}

Key words: molecular phylogeny, biogeography, molecular divergence times, Yunnan-Guizhou Plateau

\section{Introduction}

Many researchers have argued that biogeographic analyses of extant freshwater fish species can be used to reconstruct historical linkages within and between regional geographical areas and reveal aspects of the underlying diversification processes of biotic evolution (Wiley \& Mayden 1985; Mayden 1987). Proposed mechanisms have included dispersal, large- or small-scale vicariance, population divergence through isolation, and genetic drift (Wiley \& Mayden 1985; Mayden 1987). Given that freshwater fishes are confined to the lentic and lotic freshwater systems, it has been suggested that their history of evolution and the mechanisms underlying their diversification is probably more easily deciphered than for many other groups (Mayden 1988). Considerable discussion has occurred on the differentiation between divergences via dispersal versus vicariance, but the fact remains that dispersion of primary freshwater fishes depends on the formation of direct connections between drainages (Bermingham \& Martin 1998; Lundberg 1993). In recent years our understanding of diversification has been enhanced through phylogenetic inferences coupled with robust estimates of phyletic divergence times. This new approach of combining data sources can provide tremendous insight into our understanding of both the patterns and the underlying the causes of the historical diversification of lineages (Castoe et al. 2009).

The Yunnan-Guizhou Plateau is situated at the southeastern fringes of the Qinghai-Tibetan Plateau, shaping the terrace gradient from the Qinghai-Tibetan Plateau to the southeastern flood plain. The Yunnan-Guizhou Plateau is a key area in investigating biotic and environmental responses of species to the geological and geographical 
development of this region in concert with the uplift of the Qinghai-Tibetan Plateau. This area is characterized by an extremely rugged terrain made up of a series of high mountains, deeply incised gorges and extremely swift rivers (Ming \& Shi 2006). Six major river drainage basins and their associated river systems drain this topographically diverse part of the Yunnan-Guizhou Plateau.

Focused primarily on the amazing landscape of the plateau, most geological and geographical studies of this area have been concerned with the historical development of drainages, primarily relative to the uplift of the Qinghai-Tibetan Plateau, and its impact on other systems (Cheng et al. 2001; Clark et al. 2004; Ming 2007; Ming et al. 2006). Several studies have also used phylogenies of regionally indigenous fishes in concert with geological and geographical information to explain the palaeogeographical histories of the rivers during and following the uplift of the Qinghai-Tibetan Plateau (Guo et al. 2005; Peng et al. 2006).

The nemacheilid genus Homatula (Nichols 1925), as currently defined, is restricted to the eastern slope of the Qinghai-Tibetan Plateau. In the most recent study of the taxonomy of the genus, Gu and Zhang (2011) recognized 12 valid species. Homatula was originally described as a subgenus of Barbatula by Nichols (1925), based on the type species Nemacheilus potanini Günther (1896) from Minjiang (a tributary of the Yangtze River in Sichuan, China). Because species of Homatula have an adipose keel developed along the dorsal midline of the caudal peduncle, which strongly resembles that of Paracobitis (Bleeker 1863), many researchers have regarded Homatula as a synonym of Paracobitis, and traditionally ascribed all Chinese balitorid species possessing this keel to the latter genus (Zhu, S.Q. 1989). However, we follow studies by Kottelat (1990), Bănărescu and Nalbant (1995), Hu and Zhang (2010) and Gu and Zhang (2011) and treat species of these two genera as two independent lineages. Paracobitis (Bleeker 1863) was described based on the type species Cobitis malaptera Cuvier and Valenciennes (1846) from Syria. All species of Paracobitis from the western slope of the Qinghai-Tibetan Plateau have 7 branched dorsal-fin rays in the majority of individuals, and a truncate posterior margin of the upper lobe of the caudal fin. By contrast, all species from the Yunnan-Guizhou Plateau, which is situated at the eastern slope of the Qinghai-Tibetan Plateau, have 8 branched dorsal-fin rays in the majority of individuals, and a rounded posterior margin of the upper lobe of caudal fin. In light of the studies cited above, and considering these morphological differences and the large geographic disjunction in the distribution provided by the Qinghai-Tibetan Plateau, we consider these as two separate lineages: Paracobitis and Homatula. All species endemic to the western slope of the Plateau are Paracobitis, and all species endemic to eastern slope of the Plateau are Homatula.

The 12 recognized species of Homatula are distributed in five major drainages of the Yunnan-Guizhou Plateau: the Nu River (the Salween River Drainage), the Lancang River (the Mekong River Drainage), the Nanpan River (the Pearl River Drainage), the Jinsha River (the Yangtze River Drainage), and the Weihe River (the Yellow River Drainage). Distributions of the species of this lineage thus provide an unusual opportunity to examine the evolution of the headwaters of the major river systems of East Asia. These indigenous fishes are primarily constrained to riverine habitats, although they may occasionally be found in lakes and slowly flowing waters. We felt that a study of their phylogeny and biogeographic relations could provide important insights into the biogeographic effects related to the uplift of the Qinghai-Tibetan Plateau.

\section{Materials and methods}

Materials Examined. In order to reconstruct the phylogeny of Homatula and to identify related historical biogeographic events, two genes were examined in detail. These were the mitochondrial cytochrome $b$ gene (cyt $b$ ) and the nuclear recombination activating gene 1 (RAG 1). Tissue samples from 98 individuals of Homatula from eighteen localities throughout Yunnan province of China were used in this study (Fig. 1; Table 1). Specimens were identified using the keys and data found in Min et al. (2010). Recent phylogenetic studies of Cobitioidea have identified Schistura as the sister group of Homatula, and Triplophysa as the sister group of the Homatula-Schistura clade (Tang et al. 2006; Šlechtová et al. 2007). Eight species of Schistura and one species of Triplophysa were included in analysis. A total of 107 individuals were examined in this study (Table 1). However, we were constrained by the difficulty in obtaining tissue samples, especially for species recently described or resurrected from synonymy in the eastern portion of the overall range of Homatula. Thus, we were unable to include samples of Homatula nanpanjiangensis Min, Chen and Yang and Homatula oligolepis Cao and Zhu (both Nanpan River Drainage), Homatula berezowskii Günther and Homatula wujiangensis Ding \& Deng (both Yangtze River Drainage), Homatula laxiclathra Gu and Zhang (Yellow River Drainage), and Homatula erhaiensis Zhu and Cao 
(Mekong River drainage). In the cases of the Yangtze and Yellow River species, specimens from the localities in which they occur had previously been identified as Homatula variegatus Dabry de Thiersant.

TABLE 1. Species used in this study (KIZ is the abbreviation of Kunming Institute of Zoology).

\begin{tabular}{|c|c|c|c|c|}
\hline \multirow[t]{2}{*}{ SPECIES } & \multirow[t]{2}{*}{ LOCALITY/ DRAINAGE } & \multirow[t]{2}{*}{ VOUCHER NUMBER (DATE) } & \multicolumn{2}{|c|}{ GENBANK ACCESSION NUMBER } \\
\hline & & & CYT $B$ & RAG 1 \\
\hline \multicolumn{5}{|l|}{ INGROUP } \\
\hline \multirow[t]{15}{*}{ H. variegatus } & \multirow{8}{*}{$\begin{array}{l}\text { Chuxiong, Yunnan, China / } \\
\text { Jinsha River }\end{array}$} & KIZ 200406167 (2004.6.19) & HM010520 & HM010621 \\
\hline & & KIZ 200406168 (2004.6.19) & HM010592 & HM010623 \\
\hline & & KIZ 200406170 (2004.6.19) & HM010573 & HM010657 \\
\hline & & KIZ 200406171 (2004.6.19) & HМ010591 & HM010619 \\
\hline & & KIZ 200406172 (2004.6.19) & HM010593 & HM010620 \\
\hline & & KIZ 200406173 (2004.6.19) & HM010587 & HM010622 \\
\hline & & KIZ 200406174 (2004.6.19) & HM010594 & HM010641 \\
\hline & & KIZ 200406308 (2004.6.19) & HM010558 & HM010640 \\
\hline & \multirow{7}{*}{$\begin{array}{l}\text { Zhaotong, Yunnan, China / } \\
\text { Jinsha River }\end{array}$} & KIZ 200405015 (2004.5.17) & HM010598 & HM010638 \\
\hline & & KIZ 200405045 (2004.5.17) & HM010590 & HM010633 \\
\hline & & KIZ 200405046 (2004.5.17) & HМ010599 & HМ010634 \\
\hline & & KIZ 200405047 (2004.5.17) & HM010518 & HM010639 \\
\hline & & KIZ 200405048 (2004.5.17) & HM010589 & HM010635 \\
\hline & & KIZ 200405049 (2004.5.17) & HM010600 & HM010636 \\
\hline & & KIZ 200405050 (2004.5.17) & HM010601 & HM010637 \\
\hline \multirow[t]{7}{*}{ H. sp. 2} & \multirow{7}{*}{$\begin{array}{l}\text { Heilongtan, Songming, } \\
\text { Yunnan / Jinsha River } \\
\text { Muyanghe, Songming, } \\
\text { Yunnan / Jinsha River }\end{array}$} & KIZ 20050114001 (2005.1.14) & HM010493 & HM010631 \\
\hline & & KIZ 20050114002 (2005.1.14) & HМ010494 & HM010630 \\
\hline & & KIZ 20090051 (2009.11.9) & HM010489 & HM010625 \\
\hline & & KIZ 20090052 (2009.11.9) & HM010495 & HM010624 \\
\hline & & KIZ 20090053 (2009.11.9) & HМ010492 & HM010629 \\
\hline & & KIZ 20090054 (2009.11.9) & HM010511 & HM010627 \\
\hline & & KIZ 20090056 (2009.11.9) & HM010512 & HM010628 \\
\hline \multirow[t]{16}{*}{ H. longidorsalis } & \multirow{3}{*}{$\begin{array}{l}\text { Yiliang, Yunnan / Nanpan } \\
\text { River }\end{array}$} & KIZ 2008005906 (2008) & HM010500 & HM010615 \\
\hline & & KIZ 2008005908 (2008) & HМ010568 & HM010614 \\
\hline & & KIZ 2008005909 (2008) & HM010557 & HM010617 \\
\hline & \multirow{2}{*}{$\begin{array}{l}\text { Zhanyi, Yunnan / Jinsha } \\
\text { River }\end{array}$} & KIZ 20060274 (2006.12.3) & HM010522 & HM010618 \\
\hline & & KIZ 20060276 (2006.12.3) & HM010550 & HM010616 \\
\hline & \multirow{5}{*}{$\begin{array}{l}\text { Banqiao, Luoping, Yunnan / } \\
\text { Nanpan River }\end{array}$} & KIZ 20080325 (2008.9.20) & HM010579 & HM010647 \\
\hline & & KIZ 20080326 (2008.9.20) & HM010597 & HM010658 \\
\hline & & KIZ 20080328 (2008.9.20) & HM010586 & HM010645 \\
\hline & & KIZ 20080329 (2008.9.20) & HM010596 & HM010646 \\
\hline & & KIZ 20080330 (2008.9.20) & HМ010578 & HM010648 \\
\hline & \multirow{6}{*}{$\begin{array}{l}\text { Duoyihe, Luoping, Yunnan / } \\
\text { Nanpan River }\end{array}$} & KIZ 20080331 (2008.9.20) & HM010519 & HM010644 \\
\hline & & KIZ 20080334 (2008.9.20) & HМ010588 & HM010643 \\
\hline & & KIZ 20080430 (2008.9.23) & HM010575 & HM010662 \\
\hline & & KIZ 20080431 (2008.9.23) & HM010574 & HM010659 \\
\hline & & KIZ 20080432 (2008.9.23) & HM010577 & HM010660 \\
\hline & & KIZ 20080433 (2008.9.23) & HM010585 & HM010661 \\
\hline
\end{tabular}


TABLE 1. (Continued)

\begin{tabular}{|c|c|c|c|c|}
\hline \multirow[t]{2}{*}{ SPECIES } & \multirow[t]{2}{*}{ LOCALITY/ DRAINAGE } & \multirow[t]{2}{*}{ VOUCHER NUMBER (DATE) } & \multicolumn{2}{|c|}{ GENBANK ACCESSION NUMBER } \\
\hline & & & CYT $B$ & RAG 1 \\
\hline \multirow[t]{21}{*}{ H. pycnolepis } & Fengqing, Yunnan / Lancang & KIZ 20050331017 (2005.3.31) & HM010541 & HM010655 \\
\hline & \multirow{2}{*}{$\begin{array}{l}\text { Gongguoqiao, Yunlong, } \\
\text { Yunnan / Lancang River }\end{array}$} & KIZ 20041001001 (2004.10.1) & HM010523 & HM010678 \\
\hline & & KIZ 20041003008 (2004.10.3) & HM010521 & HM010677 \\
\hline & \multirow{3}{*}{$\begin{array}{l}\text { Jiuzhou, Yunlong, Yunnan / } \\
\text { Lancang River }\end{array}$} & KIZ 20041003009 (2004.10.3) & HM010549 & HM010676 \\
\hline & & KIZ 05042703 (2005.4.27) & HM010554 & HМ010656 \\
\hline & & KIZ 05043012 (2005.4.30) & HM010555 & HM010654 \\
\hline & \multirow{4}{*}{$\begin{array}{l}\text { Lanping, Yunnan / Lancang } \\
\text { River } \\
\text { Dahuaqiao, Yunnan / } \\
\text { Lancang River }\end{array}$} & KIZ 20050423003 (2005.4.23) & HM010547 & HM010632 \\
\hline & & KIZ 05050127 (2005.5.1) & HM010548 & HM010652 \\
\hline & & KIZ 05050128 (2005.5.1) & HM010559 & HM010653 \\
\hline & & KIZ 05050129 (2005.5.1) & HM010560 & HM010650 \\
\hline & \multirow[t]{4}{*}{ Lincang, Yunnan / Nu River } & KIZ 20050421001 (2005.4.21) & HM010567 & HM010681 \\
\hline & & KIZ 20050421002 (2005.4.21) & HM010553 & HM010682 \\
\hline & & KIZ 20050421004 (2005.4.21) & HM010552 & HM010679 \\
\hline & & KIZ 20050421005 (2005.4.21) & HM010501 & HM010680 \\
\hline & \multirow[t]{2}{*}{ Longling, Yunnan/ Nu River } & KIZ 07308 (2007) & HM010569 & HM010663 \\
\hline & & KIZ 07310 (2007) & HM010566 & HM010683 \\
\hline & \multirow{5}{*}{$\begin{array}{l}\text { Yangbi, Yunnan /Lancang } \\
\text { River }\end{array}$} & KIZ 20100199 (2010) & JN837646 & JN837658 \\
\hline & & KIZ 20100200 (2010) & JN837647 & JN837659 \\
\hline & & KIZ 20100201 (2010) & JN837648 & JN837660 \\
\hline & & KIZ 20100202 (2010) & JN837649 & JN837661 \\
\hline & & KIZ 20100203 (2010) & JN837650 & JN837662 \\
\hline \multirow[t]{10}{*}{ H. anguillioides } & \multirow{10}{*}{$\begin{array}{l}\text { Yousuo Spring, Yunnan / } \\
\text { Lancang River }\end{array}$} & KIZ 20080302 (2008.7.22) & HM010546 & HM010671 \\
\hline & & KIZ 20080303 (2008.7.22) & HM010529 & HM010668 \\
\hline & & KIZ 20080304 (2008.7.22) & HM010583 & HM010669 \\
\hline & & KIZ 20080305 (2008.7.22) & HM010582 & HМ010674 \\
\hline & & KIZ 20080306 (2008.7.22) & HM010584 & HM010675 \\
\hline & & KIZ 20080307 (2008.7.22) & HM010507 & HM010664 \\
\hline & & KIZ 20080308 (2008.7.22) & HM010506 & HM010666 \\
\hline & & KIZ 20080311 (2008.7.22) & HМ010508 & HM010649 \\
\hline & & KIZ 20080312 (2008.7.22) & HM010531 & HМ010667 \\
\hline & & KIZ 20080313 (2008.7.22) & HM010581 & HM010670 \\
\hline \multirow[t]{3}{*}{ H. acuticephala } & \multirow{2}{*}{$\begin{array}{l}\text { Haixihai Lake, Yunnan / } \\
\text { Lancang River }\end{array}$} & KIZ 2008005993 (2008.7) & HM010527 & HM010672 \\
\hline & & KIZ 2008005994 (2008.7) & HM010503 & HM010673 \\
\hline & $\begin{array}{l}\text { Haixihai Lake, Yunnan / } \\
\text { Lancang River }\end{array}$ & KIZ 2008005998 (2008.7) & HM010505 & HM010665 \\
\hline \multirow[t]{5}{*}{ H. sp. 1} & \multirow{5}{*}{$\begin{array}{l}\text { Jiangdong, Wuliang } \\
\text { Mountains, Yunnan / } \\
\text { Lancang River }\end{array}$} & KIZ 20080581 (2008.12.13) & HM010517 & HМ010609 \\
\hline & & KIZ 20080582 (2008.12.13) & HМ010496 & HM010612 \\
\hline & & KIZ 20080583 (2008.12.13) & HМ010543 & HM010611 \\
\hline & & KIZ 20080584 (2008.12.13) & HM010532 & HM010613 \\
\hline & & KIZ 20080587 (2008.12.13) & HM010538 & HM010610 \\
\hline
\end{tabular}


TABLE 1. (Continued)

\begin{tabular}{|c|c|c|c|c|}
\hline \multirow[t]{2}{*}{ SPECIES } & \multirow[t]{2}{*}{ LOCALITY/ DRAINAGE } & \multirow[t]{2}{*}{ VOUCHER NUMBER (DATE) } & \multicolumn{2}{|c|}{ GENBANK ACCESSION NUMBER } \\
\hline & & & CYT $B$ & RAG 1 \\
\hline \multirow{18}{*}{ H. potanini } & \multirow{9}{*}{$\begin{array}{l}\text { Jianyang, Sichuan / Jinsha } \\
\text { River }\end{array}$} & KIZ 20080588 (2008.12.13) & HM010535 & HM010607 \\
\hline & & KIZ 20080591 (2008.12.13) & HМ010544 & HM010608 \\
\hline & & KIZ 2010000231 (2010.1.28) & JF340395 & JF340427 \\
\hline & & KIZ 2010000232 (2010.1.28) & JF340394 & JF340425 \\
\hline & & KIZ 2010000233 (2010.1.28) & JF340399 & JF340420 \\
\hline & & KIZ 2010000234 (2010.1.28) & JF340396 & JF340422 \\
\hline & & KIZ 2010000235 (2010.1.28) & JF340390 & JF340423 \\
\hline & & KIZ 2010000236 (2010.1.28) & JF340400 & JF340419 \\
\hline & & KIZ 2010000237 (2010.1.28) & JF340397 & JF340421 \\
\hline & \multirow{5}{*}{$\begin{array}{l}\text { Meishan, Sichuan / Jinsha } \\
\text { River } \\
\text { Leshan, Sichuan / Jinsha } \\
\text { River }\end{array}$} & KIZ 2010000238 (2010.1.28) & JF340391 & JF340424 \\
\hline & & KIZ 2010000239 (2010.1.28) & JF340398 & JF340431 \\
\hline & & KIZ 2010000266 (2010.1.28) & JF340393 & JF340430 \\
\hline & & KIZ 2010000279 (2010.1.28) & JF340386 & JF340434 \\
\hline & & KIZ 2010000280 (2010.1.28) & JF340385 & JF340426 \\
\hline & \multirow{4}{*}{$\begin{array}{l}\text { Jianyang, Sichuan / Jinsha } \\
\text { River }\end{array}$} & KIZ 2010000281 (2010.1.28) & JF340388 & JF340388 \\
\hline & & KIZ 2010000282 (2010.1.28) & JF340387 & JF340432 \\
\hline & & KIZ 2010000283 (2010.1.28) & JF340389 & JF340428 \\
\hline & & KIZ 2010000284 (2010.1.28) & JF340392 & JF340429 \\
\hline \multicolumn{5}{|l|}{ OUTGROUP } \\
\hline $\begin{array}{l}\text { Schistura } \\
\text { fasciolata }\end{array}$ & Yunnan, China & KIZ 20050320004 & HM010513 & HM010606 \\
\hline $\begin{array}{l}\text { Schistura } \\
\text { caudofurca }\end{array}$ & Yunnan, China & KIZ 200401033 & JN837651 & JN837663 \\
\hline $\begin{array}{l}\text { Schistura } \\
\text { callichroma }\end{array}$ & Yunnan, China & KIZ 200401056 & JN837652 & JN837664 \\
\hline $\begin{array}{l}\text { Schistura } \\
\text { amplizona }\end{array}$ & Yunnan, China & KIZ 2010003103 & JN837656 & JN837668 \\
\hline $\begin{array}{l}\text { Schistura } \\
\text { latifasciata }\end{array}$ & Yunnan, China & KIZ 20050325004 & JN837653 & JN837665 \\
\hline $\begin{array}{l}\text { Schistura } \\
\text { cryptofasciata }\end{array}$ & Yunnan, China & KIZ 20050410011 & JF340401 & JF340418 \\
\hline $\begin{array}{l}\text { Schistura } \\
\text { bucculenta }\end{array}$ & Yunnan, China & KIZ 20080614 & JN837654 & JN837666 \\
\hline $\begin{array}{l}\text { Schistura } \\
\text { macrotaenia }\end{array}$ & Yunnan, China & KIZ 20100035 & JN837655 & JN837667 \\
\hline $\begin{array}{l}\text { Triplophysa } \\
\text { stenura }\end{array}$ & Yunnan, China & KIZ 20040620001 & JN837657 & JN837669 \\
\hline
\end{tabular}




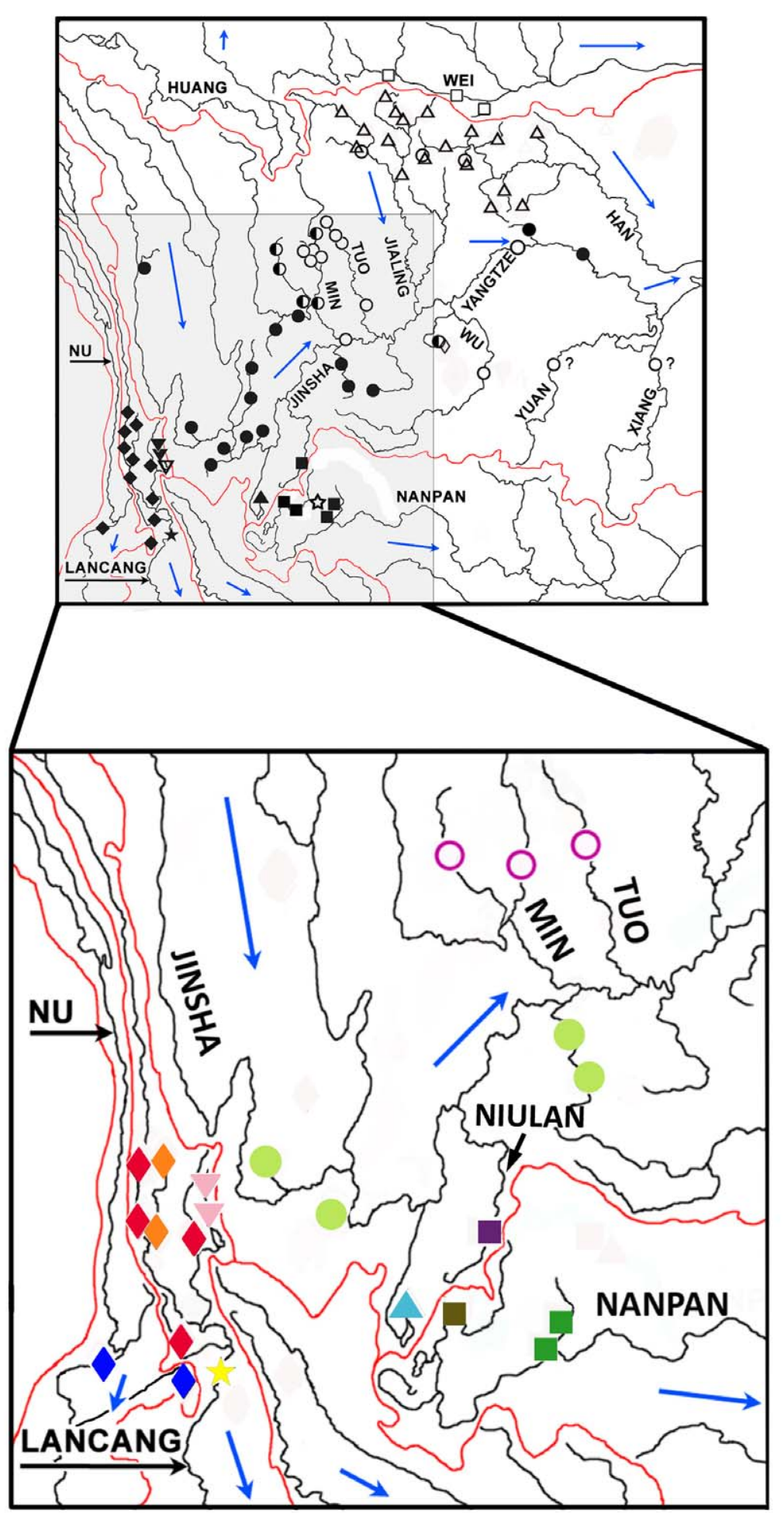

FIGURE 1. Map (above) showing the distributions of Homatula based on literature records; map (below) showing the localities of Homatula samples used in this study. The area sampled in this study is shaded in the upper map. H. pycnolepis;

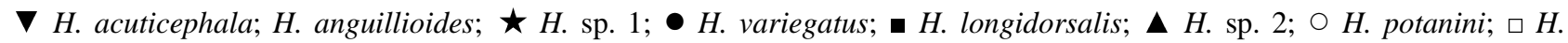
laxiclathra; $\triangle H$. berezowski; $\diamond H$. wujiangensis; $\nabla H$. erhaiensis; is H. nanpanjiangensis. Different colors represent populations from different locations, and corresponds to the colors used in Figs. 2-5. Blue arrows show the direction of water flow, red lines represent the boundaries of the main drainage basins. 
Molecular methods. Total genomic DNA was extracted using a phenol/chloroform technique (Sambrook et al. 1989). Primers used to amplify the two genes are listed in Table 2. The PCR reactions were conducted on a T3000 Thermocycler (Biomatra Inc., Germany) in $50 \mu \mathrm{l}$ volumes containing $38.5 \mu \mathrm{l}$ of double distilled water, $5 \mu 1$ of $10 \times$ reaction buffer ( $1 \%$ SDS, $50 \%$ Glycerol, $0.05 \%$ Bromophenol Blue), $3 \mu 1$ of $2.5 \mathrm{mM}$ dNTP each, $1 \mu 1$ of 10 $\mu \mathrm{M}$ of each primer, $1 \mathrm{mg}$ of bovine serum albumin, $0.5 \mu 1 \mathrm{rTaq}$ DNA polymerase (Takara, Japan) and about $50 \mathrm{ng}$ of DNA template. The following thermal cycling profiles were adopted: 95 ? predenaturing $(5 \mathrm{~min}), 95$ ? denaturing (40 s), 53? for RAG 1 or 52 ? for cyt $b$ annealing ( $40 \mathrm{~s}$ ), 72? extension ( $90 \mathrm{~s}$ ), for 35 cycles, and 72 ? final extension (7 min). PCR products were electrophoresed in 1.5\% agarose and recovered using a DNA purification kit (Sangon Inc., Shanghai, China). Sequencing of purified PCR products was performed with the BigDye Terminator Cycle Sequencing Kit (Applied Biosystems) using the same primers as those used in the PCR. DNA strands were sequenced from both directions.

TABLE 2. Primers used for both PCR amplification and sequencing in present study.

\begin{tabular}{|c|c|c|c|}
\hline Primer & Primer sequences $^{\mathrm{a}}\left(5^{\prime}-3^{\prime}\right)$ & Locus & Reference \\
\hline $\begin{array}{l}\text { L14724 } \\
\end{array}$ & GAC TTG AAA AAC CAC CGT TG & cyt $b$ & Xiao et al. 2001 \\
\hline H15915 & CTC CGA TCT CCG GAT TAC AAG AC & cyt $b$ & Xiao et al. 2001 \\
\hline RAG-1F & AGC TGT AGT CAG TAY CAC AAR ATG & RAG 1 & Perdices et al. 2005 \\
\hline RAGRV1 & TCC TGR AAG ATY TTG TAG AA & RAG 1 & Šlechtová et al. 2007 \\
\hline R1 2533F & CTGAGCTGCAGTCAGTACCATAAGATGT & RAG 1 & López et al. 2004 \\
\hline R14090R & CTGAGTCCTTGTGAGCTTCCATRAAYTT & RAG 1 & López et al. 2004 \\
\hline
\end{tabular}

${ }^{a}$ Positions with mixed bases are labeled with their IUB codes: $\mathrm{R}=\mathrm{A} / \mathrm{G} ; \mathrm{Y}=\mathrm{C} / \mathrm{T}$.

Sequence data and phylogenetic analyses. Sequences were edited in Seqman and EditSeq program of DNAStar 5 (DNASTAR Inc.) software package, aligned using the alignment explorer in MEGA ver. 4 (Tamura $e t$ al. 2007), and, if necessary, adjusted by eye. Descriptive statistics for sequence comparisons and chi-square tests tests of homogeneity of base frequencies across taxa were conducted using PAUP* 4.0b10 (Swofford 2002). Both datasets were tested for saturation by plotting the absolute number of transitions $\left(\mathrm{T}_{\mathrm{i}}\right)$ and transversions $\left(\mathrm{T}_{\mathrm{v}}\right)$ against F84 genetic distance in DAMBE (Xia 2000; Xia \& Xie 2001). Pairwise distances for two datasets were calculated in MEGA ver. 4.

The Bayesian Inference (BI) of phylogenetic reconstruction was employed using the haplotypes of each marker. Phylogenetic (gene) trees were rooted using Triplophysa stenura Herzenstein.

BI analysis was performed using MrBayes ver. 3.1.2 (Ronquist \& Huelsenbeck 2003). jModelTest 0.1 (Posada 2008; Guindon \& Gascuel 2003) was employed to investigate the evolutionary model that best fit the data set. The Akaike information criteria (AIC) specified TIM3 model $+\mathrm{I}+\mathrm{G}$ for the cyt $b$ gene and the K80 model $+\mathrm{G}$ for the RAG 1 gene. For each analysis, two independent Markov chain Monte Carlo (MCMC) processes were run for five million generations with one cold simultaneous chain and three incrementally heated chains, sampling once every 100 generations, and diagnosing once every 1000 generations, with a burn-in of the first $25 \%$. Retained trees were used to construct a $50 \%$ majority rule consensus tree indicating the posterior probabilities for nodes.

Divergence time estimation. To infer divergence times within Homatula, a likelihood ratio test (Felsenstein 1988) was performed to check whether the constant rate was supported for the cyt $b$ data set. Rate constancy in the cyt $b$ data set was supported at the $\mathrm{P}>0.05$ level. We used mtDNA for the dating analysis, mainly because it is nonrecombined and the gene provides the most powerful resolution. In the absence of a reliable fossil record for calibration or a local clock-rate estimate for Homatula, the relaxed clock option could not be used. Thus, the Bayesian Strict Clock Method for the cyt $b$ data set was employed. A Bayesian tree for estimating the divergence time was produced with BEAST 1.61 (Drummond \& Rambaut 2007) using the GTR $+\mathrm{I}+\mathrm{G}$ model, which provided the best fit for this gene. Trees were produced with 10 million MCMC steps with the Yule process under the strict clock with a constant divergence rate 2.65\%/Mry (mean divergence rate of 2.5\%-2.8\%/Mry) obtained for Lefua echigonia Jordan and Richardson (Saka et al. 2003). A maximum credibility tree was selected using TreeAnnotator 1.61 and visualized with Fig Tree 1.3.1 (A. Rambaut, http://tree.bio.ed.ac.uk/). 


\section{Results}

Sequence characteristics. The sequence information for the specimens examined in this study is listed in Table 1. The 107-taxa cyt $b$ data matrix included 1140 aligned nucleotides, of which $416(36.5 \%)$ were variable and 331 (29.0\%) were parsimony informative. The 107-taxa RAG 1 data set included 903 aligned nucleotides, of which 149 $(16.5 \%)$ were variable and $81(9.0 \%)$ were parsimony informative. The sequence characteristics for each codon position are provided in Table 3. For the two datasets, plots of the number of substitutions against F84 distances showed that both $T_{i}$ and $T_{v}$ had not reached saturation. The result of pairwise distance for two datasets see Table 4 .

TABLE 3. Sequence characteristics of two markers.

\begin{tabular}{|c|c|c|c|c|c|c|c|c|c|c|c|}
\hline \multirow[t]{2}{*}{ Marker } & \multirow[t]{2}{*}{ Sites included } & \multicolumn{3}{|c|}{ Variable sites } & \multicolumn{3}{|c|}{ Parsimony informative sites (in \%) } & \multirow[t]{2}{*}{ G } & \multirow[t]{2}{*}{$\mathrm{C}$} & \multirow[t]{2}{*}{$\mathrm{T}$} & \multirow[t]{2}{*}{ A } \\
\hline & & $1^{\mathrm{st}}$ & $2^{\text {nd }}$ & $3^{\text {rd }}$ & $1^{\text {st }}$ & $2^{\text {nd }}$ & $3^{\text {rd }}$ & & & & \\
\hline Rag1 & 903 & 32 & 9 & 108 & $16(5.32)$ & $4(1.33)$ & $61(20.27)$ & 29.28 & 26.29 & 21.88 & 22.55 \\
\hline Cyt $b$ & 1140 & 78 & 17 & 321 & $56(14.74)$ & $3(0.79)$ & $272(71.58)$ & 15.50 & 27.27 & 28.72 & 28.52 \\
\hline
\end{tabular}

TABLE 4. Pairwise distance for two datasets in $p$-distance.

\begin{tabular}{lllll}
\hline & Overall & $\begin{array}{l}\text { average within } \\
\text { Homatula }\end{array}$ & $\begin{array}{l}\text { net between Homatula } \\
\text { and Schistura }\end{array}$ & $\begin{array}{l}\text { average between Homatula } \\
\text { and outgroups (Triplophysa } \text { and Schistura) }\end{array}$ \\
\hline Cyt $b$ & 0.087 & 0.067 & 0.059 & 0.132 \\
Rag1 & 0.030 & 0.020 & 0.018 & 0.049 \\
\hline
\end{tabular}

Phylogenetic analyses of protein-coding genes can be biased by the occurrence of homoplasy at the third codon position due to multiple substitutions in transitions (Saitoh et al. 2006) and/or due to base composition bias across taxa (Lockhart et al. 1994; Chen et al. 2003). The $\chi^{2}$ base composition test was not significant (8.065, d.f. $=$ $318, P=1.00000$ for the RAG 1 gene; 47.689 , d.f. $=318, P=1.00000$ for the cyt $b$ gene); the $\chi^{2}$ base composition test for each $3^{\text {rd }}$ position was not significant $(1.446195$, d.f. $=318, P=1.00000$ for the RAG 1 gene; 170.034 , d.f. $=$ $318, P=1.00000$ for the cyt $b$ gene).

Phylogenetic relationships. Bayesian analyses of the two data sets are fully resolved with respect to the taxa included in this study (Figs. 2 and 3). The following relationships were indicated. The monophyly of the genus Homatula, with respect to outgroups, was supported (Bayesian posterior probability $(\mathrm{PP})=1.00$ ). The monophyly of $H$. sp. 1 and $H$. sp. 2 was supported ( $\mathrm{PP}=1.00)$. Five clades were identified in our phylogenetic analysis. Clade I: a basal lineage represented by $H$. sp. 1 from a stream in the Wuliang Mountains (flowing into the Lancang River). Clade II: a lineage consisting of Homatula pycnolepis $\mathrm{Hu}$ and Zhang from the $\mathrm{Nu}$ and Lancang Rivers plus Homatula anguillioides Zhu and Wang plus Homatula acuticephala Zhou and He (see below) from Yousuo, endemic to the Erhai basin (Lancang River drainage). Clade III: a lineage represented by Homatula potanini Günther from the Jinsha River. Clade IV: composed of $H$. sp. 2 from Songming (Jinsha River drainage). Clade V: contains two sub-clades. One subclade consisted of samples of both $H$. variegatus Dabry de Thiersant (Jinsha River) and Homatula longidorsalis Yang, Chen and Kottelat. (Lower Nanpan). The other sub-clade contained only specimens identified as $H$. longidorsalis, but the samples were from both the Jinsha and the Upper Nanpan Rivers.

Conflicts between the gene tree topologies were detected in the following instances: the subclade of $H$. anguillioides plus $H$. acuticephala from Eryuan area and the H. variegatus/H. longidorsalis group. With the cyt $b$ data set (Fig. 2), the subclade of $H$. acuticephala plus $H$. anguillioides from Eryuan area was nested within $H$. pycnolepis from the $\mathrm{Nu}$ and Lancang Rivers; the separation of $H$. variegatus and $H$. londidorsalis was not supported. In the RAG 1 gene tree (Fig. 3), the subclade of $H$. anguillioides plus $H$. acuticephala from Eryuan area formed a monophyletic sub-clade with strong support $(\mathrm{PP}=1.00)$ and was the sister group of a monophyletic $H$. pycnolepis. Furthermore, while the monophyly of $H$. longidorsalis was supported with PP of 0.96 , that lineage formed a trichotomy with two separate populations of $H$. variegatus. 


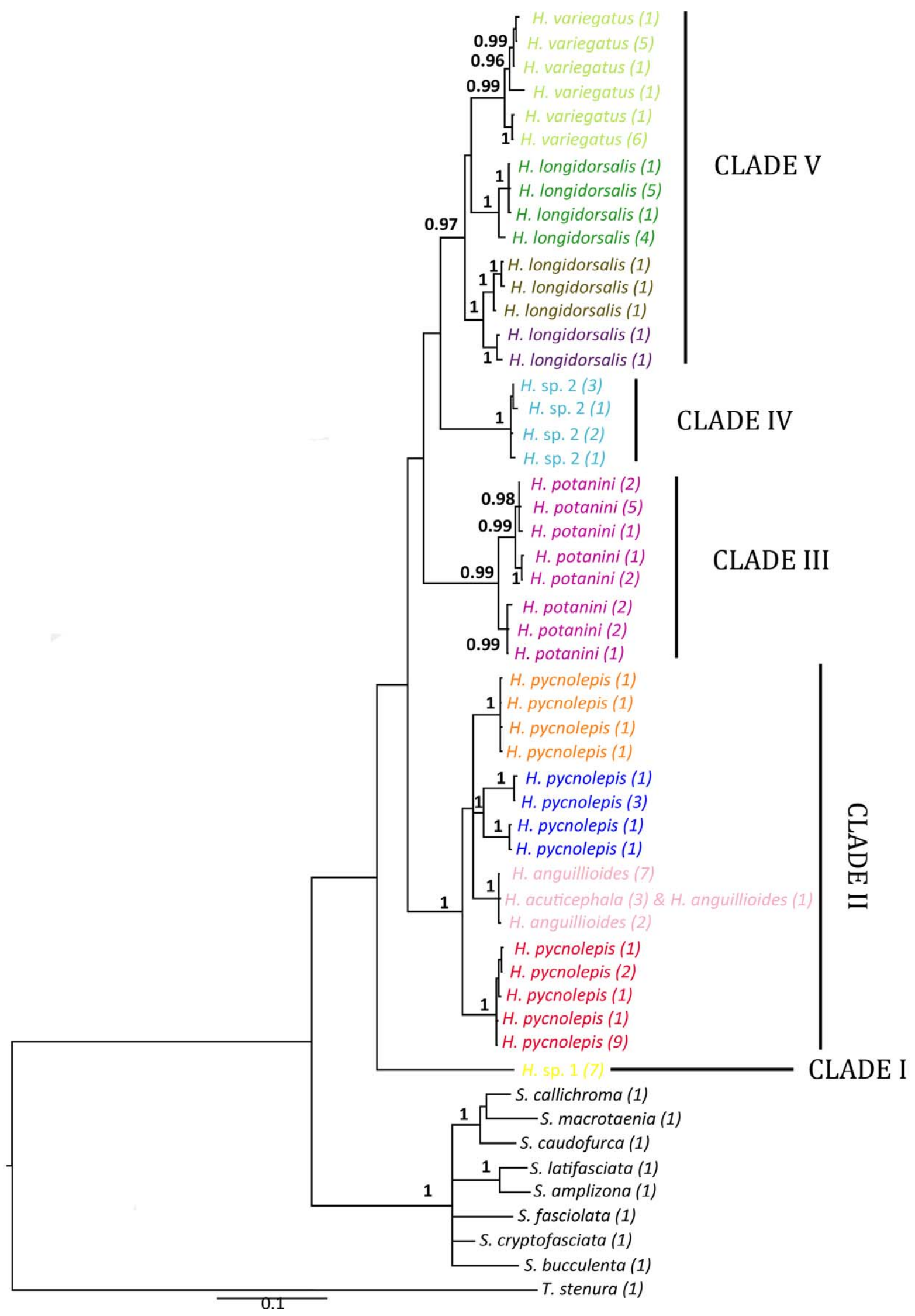

FIGURE 2. $50 \%$ major-rule consensus of the Bayesian tree based on the cyt $b$ data set with 53 haplotypes. Numbers on node indicate Bayesian posterior probabilities. Numbers in brackets represent the samples of each haplotype. Colors represent population from different locations (see Fig. 1). 


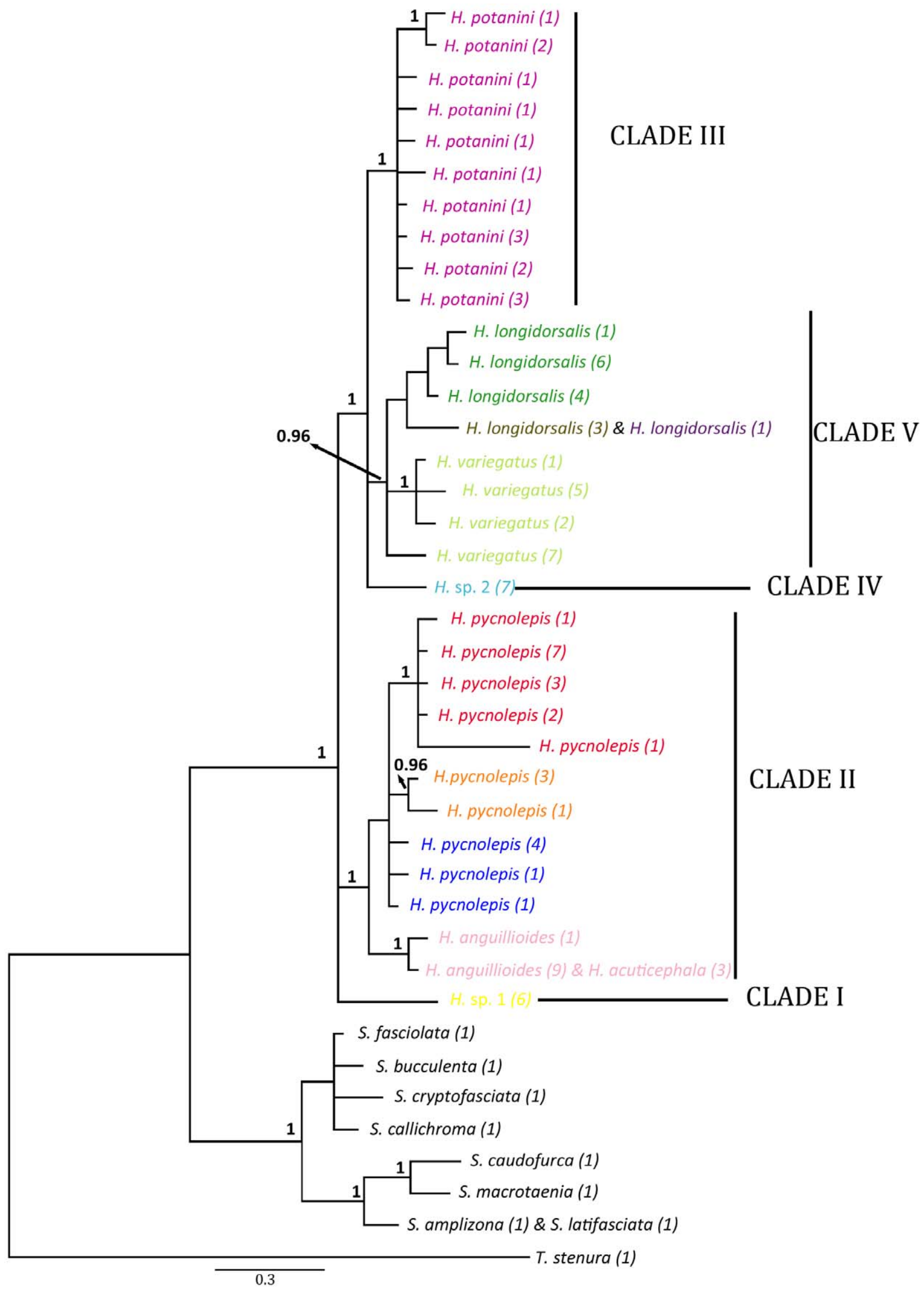

FIGURE 3. $50 \%$ major-rule consensus of the Bayesian tree based on the RAG 1 data set with 40 haplotypes. Numbers on node indicate Bayesian posterior probabilities. Numbers in brackets represent the samples of each haplotype. Colors represent population from different locations (see Fig. 1). 


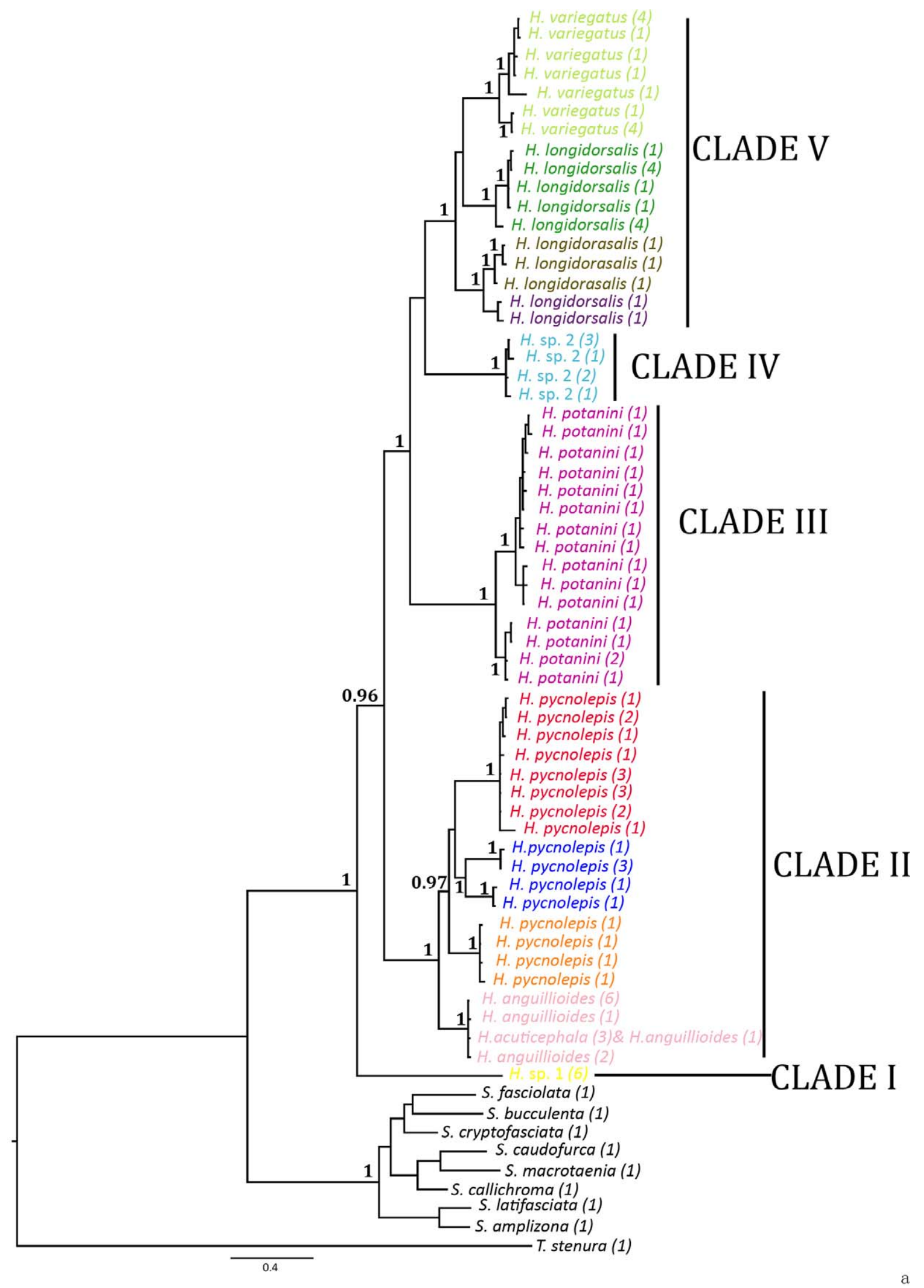

FIGURE 4. $50 \%$ major-rule consensus of the Bayesian tree based on the combined data set with 66 haplotypes. Numbers on node indicate Bayesian posterior probabilities. Numbers in brackets represent the samples of each haplotype. Colors represent population from different locations (see Fig. 1). 
Estimation of lineage divergence times. Our dating analyses suggest that Homatula originated during the late Pliocene. The major clades were estimated to have diverged during the following times respectively: clade I $(H$. sp. 1) originated around $3.59 \mathrm{Ma}$; clade II diverged from clade III, IV and V around $2.78 \mathrm{Ma}$. Within clade III-V, the lineages were estimated to have diverged at the following approximate times: clade III originated around $2.43 \mathrm{Ma}$; lineage IV diverged from lineage $\mathrm{V}$ about 1.95 Ma (Fig. 5).

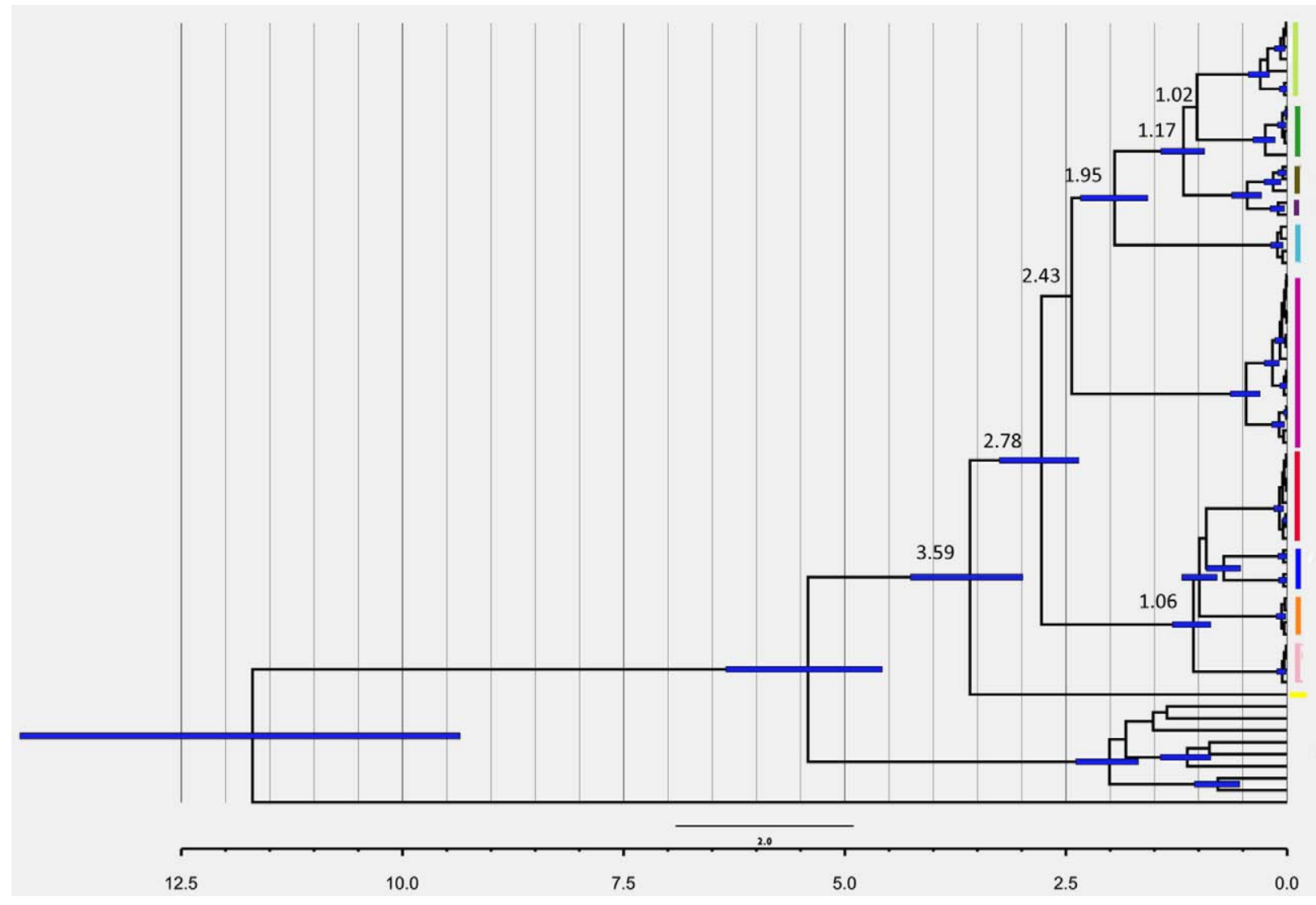

FIGURE 5. Bayesian estimates of divergence time for the Homatula phylogeny based on the cyt $b$ data set. Bars represent $95 \%$ credibility intervals for divergence estimates. Numbers on nodes are million years ago (Ma). Colors represent population from different locations (see Fig. 1).

\section{Discussion}

Phylogenetic relationships. Our phylogenetic analyses (Figs. 2 and 3) strongly support the monophyly of Homatula, a genus confined to five major drainage basins in China. Since the two trees obtained differed in some details, we used a 50\% majority-rule consensus tree derived from the concatenated data set (Fig. 4).

Our analysis indicates that $H$. acuticephala is nested well within the samples of $H$. anguillioides that we examined. Homatula acuticephala was described by Zhou and He (1993), and was distinguished from $H$. anguillioides by having a body which is depressed posteriorly from the origin of the dorsal fin (vs. a uniform body depth); a pectoral fin reaching less than half the distance between the origin of the pectoral fin and the origin of the pelvic fin (vs. equal to or slightly less); and 40-42 vertebrae (vs. 40). Our samples from the type locality of $H$. acuticephala (Haixihai Lake) are all juveniles, and the first three putative differences are not apparent. Considering the contradiction between our molecular results and the morphological characters, the status of $\mathrm{H}$. acuticephala needs further examination, but we strongly suspect that it will prove to be a junior subjective synonym of $H$. anguillioides. Consequently, we treat all these samples as the latter species in the biogeographic analysis (below).

The distribution of museum specimens originally identified as $H$. variegatus included the upper Yangtze, the Yellow (Wei River) and the Nanpan drainages. However, recent work (Hu \& Zhang 2010; Min et al. 2010; Gu \& Zhang 2011) has shown that a complex of different species is involved. Populations from the Upper Nanpan River (brown symbol on map, Fig. 1) were separated from H. variegatus by Yang et al. (1994) as a new subspecies, $H$. 
variegatus longidorsalis. The major morphological differences cited between two subspecies were the number of branched dorsal-fin rays, the morphology of anterior nostril, the color pattern of head, and the length of maxillary barbels (Yang et al. 1994). Although Hu and Zhang (2010) regarded H. v. longidorsalis as a junior synonym of $H$. variegatus, Gu and Zhang (2011) resurrected as a full, valid species. Additional collecting since that time has revealed the presence of the H. longidorsalis morphotype in a tributary of the Jinsha River (the Niulan Jiang - dark purple symbol, Fig. 1) almost due north of the Upper Nanpan samples. Although the monophyly of H. variegatus was supported by our analyses, the monophyly of the two subspecies was not (cf. Figs. 2, 3 and 5). In the concatenated tree, H. variegatus (lime-green symbol in Fig. 1) forms a monophyletic subunit which is the sister group of the specimens of $H$. longidorsalis from the Lower Nanpan River (dark green symbol in Fig. 1). These two together form the sister group of the specimens identified as H. longidorsalis from the Upper Nanpan (the type locality of this species) plus the Niulan branch of the Jinsha. Given the disagreement between the molecular tree and the morphology, it is clear that much further work needs to be undertaken to resolve the phylogeographic relationships among the population of $H$. variegatus throughout its range, and we will treat it further here only at the specific level.

The results of the concatenated data set derived from Cytochrome $b$ and RAG 1 can be expressed as $(H$. sp. 1 (H. anguillioides, H. pycnolepis) (H. potanini (H. sp. 2, H. variegatus))).

Biogeographic relationships. Optimization of the area cladogram derived from Fig. 4 suggests the following area relationships (Fig. 6A). The common ancestor of all extant species of Homatula occupied the Lancang River. A speciation event occurred within the Lancang system, resulting in the lineage leading to $H$. sp. 1 and the ancestor of the lineage that led to all the remaining species. Since the area occupied by the former is extremely small relative to the latter, this is likely to be due to a peripheral isolation mechanism (sensu Lynch 1989). The latter ancestor (Clade II, Fig. 4) split into the ancestor of H. pycnolepis + H. anguillioides (confined to the Lancang and Nu river systems) on the one hand and to the common ancestor of the three remaining species of Homatula (presently confined to rivers draining to the east of the Lancang) on the other. The first of the above lineages (Clade II) separated into $H$. pycnolepis (widely distributed in the $\mathrm{Nu}$ and Lancang river systems) and $H$. anguillioides (confined to the northern tributary of Erhai Lake). Given the broad distribution of the former relative to the confined range of the latter, the peripheral isolation mode of speciation again seems to be indicated.

It is not possible, on the basis of the present evidence, to decipher whether the physical separation of the lineage leading to $H$. potanini, $H$. sp. 2 and $H$. variegatus from the Lancang populations was the result of this speciation event, i.e., whether, in an allopatric model of speciation, the actual speciation event occurred within the Lancang system, or after the separation of the ancestral population into one in the Lancang and the other in the more easterly drainages (which the optimization of current distributions suggests was the Yangtze).

The common ancestor of the three remaining extant lineages then separated into the ancestor of $H$. potanini (currently widely distributed in the Jinsha and its tributaries as well as the Han, and possibly the Yuan and Xiang rivers, all within the Yangtze system) and the common ancestor of $H$. sp. 2 and $H$. variegatus. The broad and overlapping distributions of these two lineages are congruent with a hypothesis of sympatric speciation, although allopatric speciation followed by dispersal cannot be ruled out.

The final event was the separation of the ancestor of $H$. sp. 2 (confined to the northern tributary stream of Lake Dianchi) and the ancestor of $H$. variegatus (in most of the Jinsha River system). Again, given the disparate sizes of the ranges of these sister species, peripheral isolation is the probable speciation mode.

We recognize that our analysis is incomplete due to the lack of samples, especially from the easterly part of the range. Three of the species recognized by Gu and Zhang (2011) occur in the northeastern streams and rivers of the area (H. berezowskii, H. laxiclathra and H. wujiangensis). However, we hypothesize, based on distribution and overall morphology, that these taxa will be members of the lineage representing Clades III-V, and thus not relevant to the basal biogeographic pattern presented herein. The three other species omitted from the analysis all have very restricted distributions. Two of these are from the Nanpan River system (H. nanpanjiangensis, a single locality on the Niujie River) and $H$. oligolepis (Yangzong Lake), and also appear to be members of Clade III-V. The last species unavailable for this analysis is H. erhaiensis (ErHai Lake only). Given our conclusion that H. acuticephala is a synonym of $H$. anguillioides, and that these two nominal species are only found in a short tributary and lake just to the north of ErHai Lake, it seems highly likely that $H$. erhaiensis is nested within Clade II. Thus, none of these three species would be expected to alter our hypothesized patterns and the basal biogeographic sequence presented here. 
A

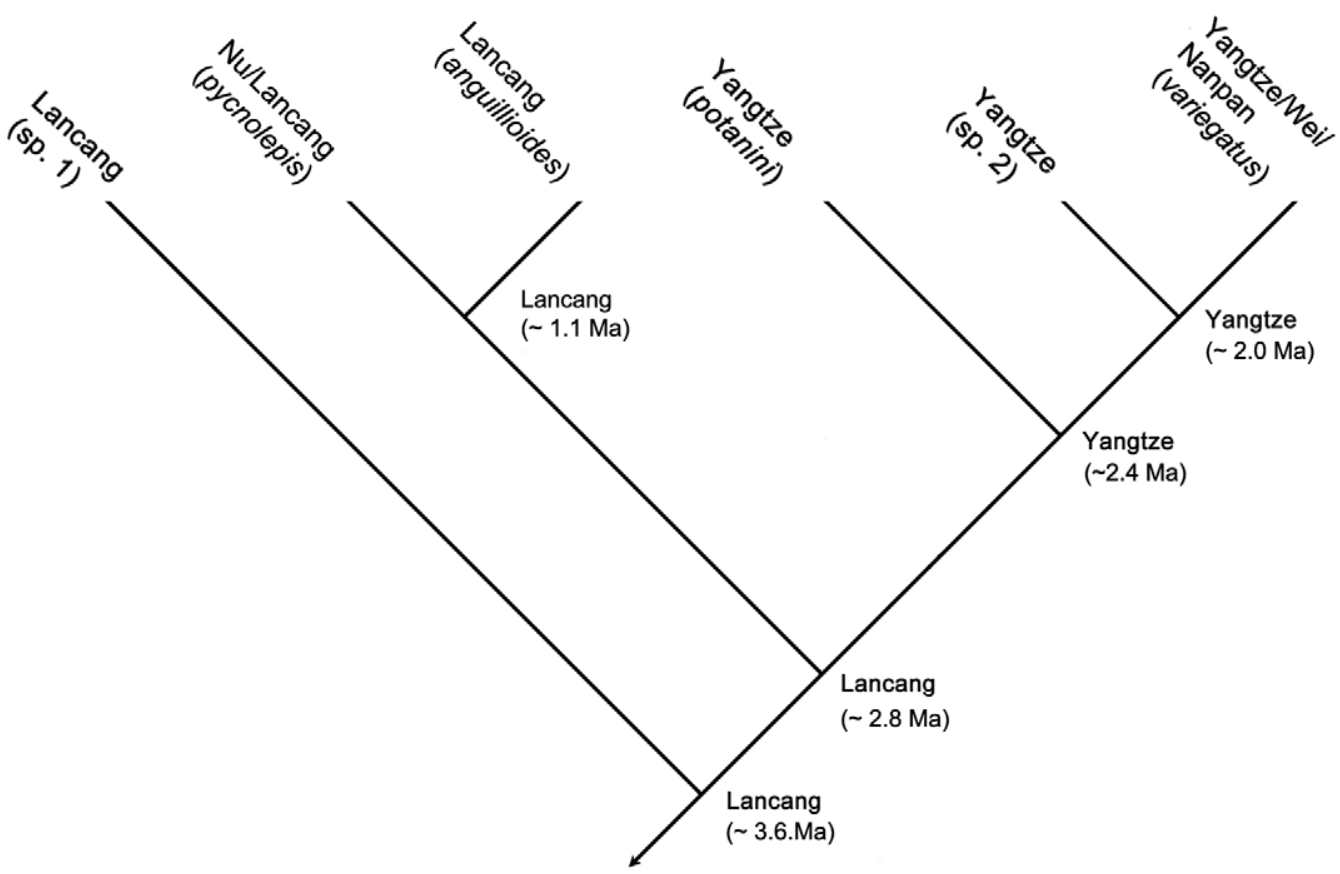

B

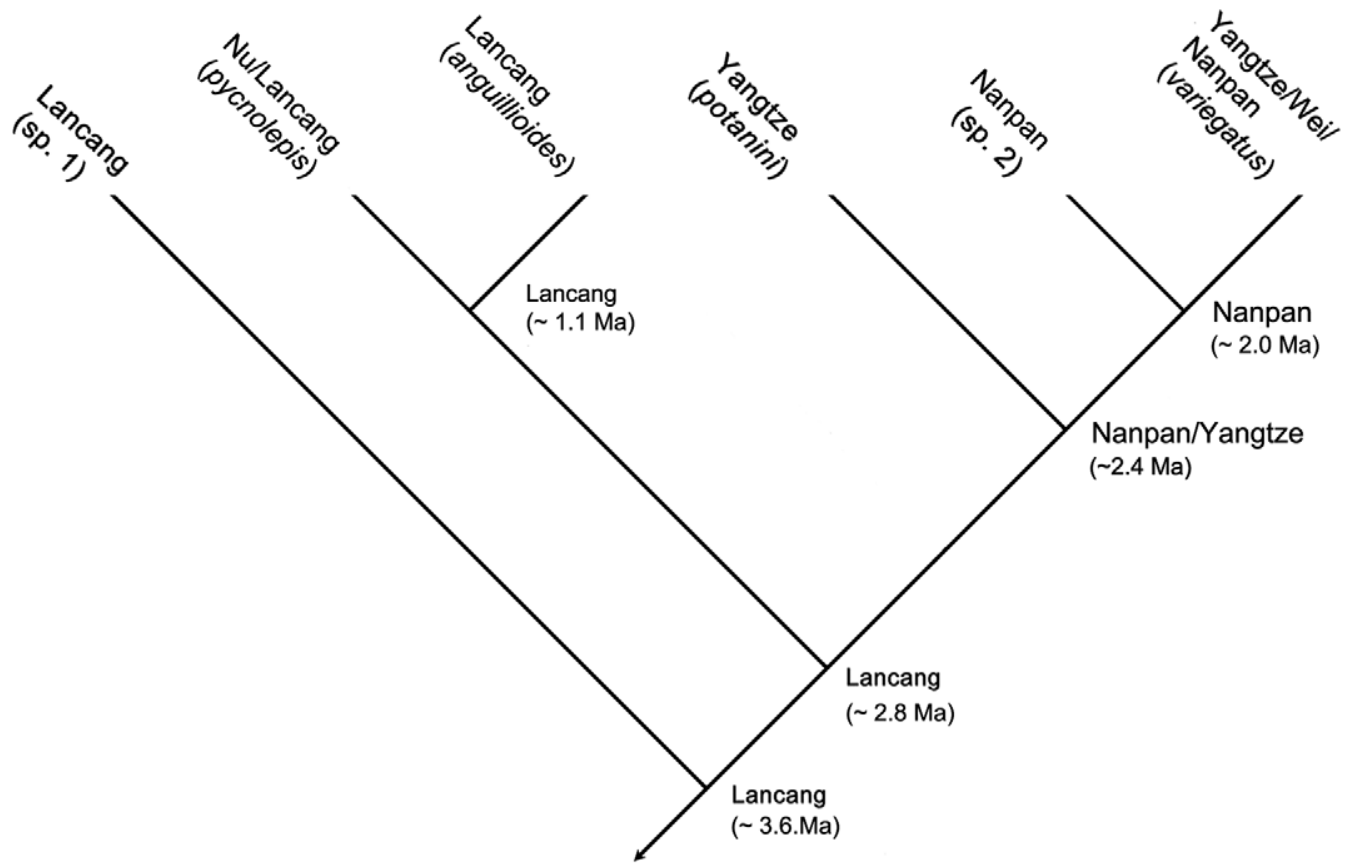

FIGURE 6. Optimization of distributions on an area cladogram. (A) Optimization based on current distributions; (B) Optimization based on incorporation of geological data into current distributions.

Divergence events. The massive Quaternary uplifting of the Qinghai-Tibetan Plateau during the Late Pliocene and the Early Pleistocene resulted from the collision of the Indian and Eurasian Plates. This event, known as the Qingzang Tectonic Movement, took place in three phases (Phases A, B, and C-see Li et al. 1996, Shi et al. 1999).

The divergence dates of the two initial clades of Homatula are congruent with the geological events associated with the uplift of the Qinghai-Tibetan Plateau, which was followed by the formation of the modern drainage 
patterns. The time of divergence of the lineage leading to $H$. sp. 1, at around 3.59 Ma (Fig. 5), is very close to Phase A of the Qingzang Tectonic Movement, which has been determined to have occurred around 3.6 Ma (Li et al. 2001; Shi et al. 1999). This tectonic movement resulted in the breakup of the surface of the plateau and likely of those rivers flowing over this landscape. The rise of the Wuliang Mountain around this time on the southwestern slope of the Yunnan-Guizhou Plateaumay well have created a barrier and isolated the common ancestor into two independent lineages: the ancestor of the lineage represented today by $H$. sp. 1 and a second ancestral lineage that subsequently evolved into all other species of Homatula (Figs. 2, 3 and 4).

Two lineage-splitting events in Homatula can be inferred to have occurred at about the time of Phase B of the Qingzang Tectonic Movement (about 2.5 Ma): 1) the divergence of the common ancestor of $\mathrm{H}$. anguillioides and H. pycnolepis on the one hand and the common ancestor of $H$. potanini, $H$. sp. 2 and $H$. variegatus on the other, both dated at about $2.8 \mathrm{Ma}$, and 2) separation in the lineage giving rise to $H$. potanini from the common ancestor of H. sp. 2 and H. variegatus, dated at about 2.4 Ma (Fig. 5). Phase B of the Qingzang Tectonic Movement was a strong orogenic movement that resulted in the massive uplifting of the Qinghai-Tibetan Plateau to a mean elevation of $1500 \mathrm{~m}$ to $2000 \mathrm{~m}$ ( $\mathrm{Li}$ et al. 2001; Shi et al. 1999). Since the Yunnan-Guizhou Plateau is situated at the eastern fringe of the Qinghai-Tibetan Plateau, many geologists have proposed that a corresponding contemporaneous uplift movement should have also occurred in this area (e.g. Sun \& Zheng 1998). The age we obtained for the separation of the ancestors of $H$. anguillioides $+H$. pycnolepis and the clade $H$. potanini, $H$. sp. 2 plus $H$. variegatus (2.8 Ma) might suggest that the isolation of the Lancang River from the Yangtze River occurred around this time. However, the role of geological forces in the separation of the ancestor of $H$. potanini on the one hand and the ancestor of $H$. sp. $2+H$. variegatus on the other $(2.4 \mathrm{Ma})$ is obfuscated by the extensive sympatry presently exiting between $H$. potanini and $H$. variegatus.

During Phase C of the Qingzang Tectonic Movement (1.7 Ma), the Qinghai-Tibetan Plateau was uplifted sharply from a mean elevation of $2000 \mathrm{~m}$ to $2500 \mathrm{~m}$, and is thought to have resulted in the formation of the modern river drainage patterns (Shi et al. 1999; Li et al. 2001). This date is approximately congruent with the separation of the ancestor of $H$. sp. 2 and $H$. variegatus (1.95 Ma). We note that Lake Dianchi formed during the Late Pliocene (pre-2009 definition used here), with a drainage outlet to the Nanpan river system. This drainage was captured by the Jinsha River during the Holocene (within the last 100,000 years, Zhu, H.H. 1989). Given that the date of the speciation of these two species coincides with the formation of Lake Dianchi, the original distribution for $H$. sp. 2 must be the Nanpan, not the Jinsha (Yangtze). This interpretation substantially alters the optimization (see Fig. 6B), suggesting that the ancestor of these two species inhabited the Nanpan (not the Yangtze), and that the split between this ancestor and the ancestor of $H$. potanini occurred between the Nanpan and Yangtze, implying that the current occurrence of $H$. variegatus in the Yangtze is secondary.

The most recent speciation event uncovered in our analysis is the separation of $H$. pycnolepis and $H$. anguillioides from their common ancestor some 1.1 Ma. The latter species is confined to the drainage system at the northern margin of Erhai Lake, which formed during the early Pleistocene (pre-2009 definition). The timing of these two events is roughly compatible, and congruent with the formation of the lake initiating speciation.

However, it should be borne in mind that these scenarios are based on a single lineage of six species. Additional phylogenetic trees of additional taxa are needed to evaluate this hypothesis and should be conducted together with time analyses to ensure that divergences are in congruent with the timing and processes outlined here. Whether or not the results we present here are part of a larger biogeographic pattern requiring a general explanation must await additional, larger-scale phylogenetic analyses.

\section{Acknowledgments}

We would like to thank all the people who helped with the collection of specimens used in this study, including Lina Du, Lan-ping Zheng, Jian Yang, Xiao-fu Pan and Wei-ying Wang. We would like to thank Guo-hua Yu, Feng Dong and Kai He for suggestions on data analysis. We also thank Li Jia for help during experiments. This work was funded by the Knowledge Innovation Program of the Chinese Academy of Sciences (KSCX2-YW-Z-0922), the National Natural Science Foundation of China (30730017), Yunnan Provincial Science and Technology Program (2009CC008), and National Science Foundation (USA) Cypriniformes Assembling the Tree of Life (EF 0431326). 


\section{References}

Bănărescu, P. \& Nalbant, T.T. (1995) A generical classification of Nemacheilinae with description of two new genera (Teleostei: Cypriniformes: Cobitidae). Travaux du Museum d'Histoire Naturelle "Grigore Antipa", 35, 429-495.

Bermingham, E. \& Martin, A.F. (1998) Comparative mtDNA phylogeography of neotropical freshwater fishes: testing shared history to infer the evolutionary landscape of lower Central America. Molecular Ecology, 7, 499-517.

Bleeker, P. (1863) Sur les genres de la famille des Cobitioïdes. Verslagen en Mededeelingen der Koninklijke Akademie van Wetenschappen. Afdeling Natuurkunde, 15, 32-44.

Castoe, T.A., Daza, J.M., Smith, E.N., Sasa, M.M., Kuch, U., Campbell, J.A., Chippindale, P.T. \& Parkinson, C.L. (2009) Comparative phylogeography of pitvipers suggests a consensus of ancient Middle American highland biogeography. Journal of Biogeography, 36, 88-103.

Chen, W.J., Bonillo, C. \& Lecointre, G. (2003) Repeatability of clades as a criterion of reliability: a case study for molecular phylogeny of Acanthomorpha (Teleostei) with larger number of taxa. Molecular Phylogenetics and Evolution, 26, 262-288.

Cheng, J., Liu, X.Q., Gao, Z.J., Tang, D.X. \& Yue, J.W. (2001) Effect of the Tibetan Plateau uplifting on geological environment of the Yunnan Plateau. Geocience, 3, 290-296.

Clark, M.K., Schoenbohm, L.M., Royden, L.H., Whipple, K.X., Burchfiel, B.C., Zhang, X., Tang, W., Wang, E. \& Chen, L. (2004) Surface uplift, tectonics, and erosion of eastern Tibet from large-scale drainage patterns. Tectonics, 23, 1-20.

Cuvier, G. \& Valenciennes, A. (1846) Histoire naturelle des poissons. Tome dix-huitième. Suite du livre dix-huitième. Cyprinoïdes. Livre dix-neuvième. Des Ésoces ou Lucioïdes. Histoire naturelle des poissons, 18, 1-553.

Drummond, A.J. \& Rambaut, A. (2007) BEAST: Bayesian evolutionary analysis by sampling trees. BMC Evolutionary Biology, 7, 214.

Felsenstein, J. (1988) Phylogenies from Molecular Sequences: Inference and Reliability. Annual Review of Genetics, 22, $521-565$.

Gu, J.H. \& Zhang, E. (2011) Homatula laxiclathra (Teleostei: Balitoridae), a new species of nemacheiline loach from the Yellow River drainage in Shaanxi Province, northern china. Environmental Biology of Fishes, 94, 591-599.

Guindon, S. \& Gascuel, O. (2003) A simple, fast, and accurate algorithm to estimate large phylogenies by maximum likelihood. Systematic Biology, 52, 696-704.

Günther, A. (1896) Report on the collections of reptiles, batrachians and fishes made by Messrs. Potanin and Berezowski in the Chinese provinces Kansu and Sze-chuen. Ezhegodnik. Zoologicheskogo Muzeya Akademii Nauk SSSR, 1986, 1, $199-219$.

Guo, X.G., He, X.P. \& Zhang, Y.G. (2005) Phylogeny and biogeography of Chinese sisorid catfishes re-examined using mitochondrial cytochrome $b$ and 16S rRNA gene sequences. Molecular Phylogenetics and Evolution, 35, 334-362.

Hu, Y.T. \& Zhang, E. (2010) Homatula pycnolepis, a new species of nemacheiline loach from the upper Mekong drainage, South China (Teleostei: Balitoridae). Ichthyology Exploration of Freshwaters, 21, 51-62.

Kottelat, M. (1990) Indochinese Nemacheilines, A Revision of Nemacheiline Loaches (Pisces: Cypriniformes) of Thailand, Burma, Laos, Cambodia and Southern Viet Nam. Verlag Dr. Friedrich Pfeil, München, 262 pp.

Li, J.J., Fang, X.M., Ma, H.Z., Zhu, J.J., Pan, B. \& Chen, H.L. (1996) Geomorphological and environmental evolution in the upper reaches of the Yellow River during the late Cenozoic. Science In China (Series D), 39, 380-390.

Li, J.J., Fang, X.M., Pan, B.T., Zhao, Z.J. \& Song, Y.G. (2001) Late Cenozoic intensive uplift of Qinghai-Xizang Plateau and its impacts on environments in surrounding area. Quaternary Sciences, 21(5), 381-391.

Lockhart, P.J., Steel, M.A., Hendy, M.D. \& Penny, D. (1994) Recovering evolutionary trees under a more realistic model of sequence evolution. Molecular Biology and Evolution, 11, 605-612.

López, J.A., Chen, W.J. \& Ortí, G. (2004) Esociform phylogeny. Copeia, 2004(3), 449-464.

Lundberg, J.G. (1993) African-South American freshwater fish clades and continental drift: problems with a paradigm. In: Goldblatt, P. (Ed), Biological Relationships between Africa and South America. Yale University Press, New Haven, pp. 156-199.

Lynch, J.D. (1989) The gauge of speciation: on the frequencies of modes of speciation. In: Otte, D. \& Endler, J. A. (Eds), Speciation and its consequences. Sinauer, Sunderland, Mass, pp. 527-553.

Mayden, R.L. (1987) Historical ecology and North American highland fishes: A research program in community ecology. In: Matthews, W. J. \& Heins, D. C. (Eds), Community and Evolutionary Ecology of North American Stream Fishes. University of Oklahoma Press, Norman, pp. 210-222.

Mayden, R.L. (1988) Vicariance biogeography, parsimony, and evolution in North American freshwater fishes. Systematic Zoology, 37, 331-357.

Min, R., Chen, X.Y. \& Yang, J.X. (2010) Paracobotis nanpanjiangensis, a new loach (Balitoridae: Nemacheilinae) from China. Environmental Biology of Fishes, 87, 199-204.

Ming, Q.Z., Shi, Z.T. \& Zhang, H.C. (2006) The Evolution of the Landform and Environment in the Region of the Three Parallel Rivers. Tropical Geography, 26, 119-122.

Ming, Q.Z. \& Shi, Z.T. (2006) The tentative inquiry on the formation time in the region of Three Parallel Rivers. Yunan Geographic Environment Research, 18, 1-4.

Ming, Q.Z. (2007) A study of the Neotectonic division \& environment evolution of Qing-zang Plateau \& Three Parallel River area. Yunnan Geology, 4, 387-396. 
Nichols, J.T. (1925) Nemacheilus and related loaches in China. American Museum Novitates, 171, 1-7.

Peng, Z.G., Ho, S.Y.W., Zhang, Y.G. \& He, S.P. (2006) Uplift of the Tibetan plateau: Evidence from divergence times of glyptosternoid catfishes. Molecular Phylogenetics and Evolution, 39, 568-572.

Perdices, A., Doadrio, I. \& Bermingham, E. (2005) Evolutionary history of the synbranchid eels (Teleostei: Synbranchidae) in Central America and the Caribbean islands inferred from their molecular phylogeny. Molecular Phylogenetics and Evolution, 37, 460-473.

Posada, D. (2008) jModelTest: Phylogenetic Model Averaging. Molecular Biology and Evolution, 25, 1253-1256.

Ronquist, F. \& Huelsenbeck, J.P. (2003) MrBayes 3: Bayesian phylogenetic inference under mixed models. Bioinformatics, 19, 1572-1574.

Saitoh, K., Sado, T., Mayden, R.L., Hanzawa, N., Nakamura, K., Nishida, M. \& Miya, M. (2006) Mitogenomic evolution and interrelationships of the Cypriniformes (Actinopterygii: Ostariophysi): the first evidence towards resolution of higherlevel relationships of the world's largest freshwater-fish clade based on 59 whole mitogenome sequences. Journal of Molecular Evolution, 63, 826-841.

Saka, R., Takehana, Y., Suguro, N. \& Sakaizumi, M. (2003) Genetic population structure of Lefua echigonia inferred from allozymic and mitochondrial cytochrome $b$ variations. Ichthyology Research, 50, 301-309.

Sambrook, J., Fritsch, E.F. \& Maniatis, T. (1989) Molecular cloning: a laboratory manual, 2nd edn. Cold Spring Harbor Laboratory Press, Cold Harbor, NY, USA.

Shi, Y.F., Li, J.J., Li, B.Y., Yao, T.D., Wang, S.M., Li, S.J., Cui, Z.J., Wang, F.B., Pan, B.T., Fang, X.M. \& Zhang, Q.S. (1999) Uplift of the Qinghai-Xizang (Tibetan) Plateau and East Asia environmental change during late Cenozoic. Acta Geographica Sinica, 54(1), 10-21.

Šlechtová, V., Bohlen, J., Tan, H.H. (2007) Families of Cobitoidea (Teleostei: Cypriniformes) as revealed from nuclear genetic data and the position of the mysterious genera Barbucca, Psilorhynchus, Serpenticobitis and Vaillantella. Molecular Phylogenetics and Evolution, 44, 1358-1365.

Sun, H.L. \& Zheng, D. (1998) Formation, evolution and development of Qinghai-Xizang (Tibetan) Plateau. Guangdong Science \& Technology Press, Gangzhou China, 350pp.

Swofford, D.L. (2002) PAUP*: Phylogenetic analysis using Parsimony (*and other methods), Version 4. Sinauer Associates, Sunderland, Massachusetts.

Tamura, K., Dudley, J., Nei, M. \& Kumar, S. (2007) MEGA4: Molecular Evolutionary Genetics Analysis (MEGA) software version 4.0. Molecular Biology and Evolution, 24, 1596-1599.

Tang, Q.Y., Liu, H.Z., Richard, M. \& Xiong, B.X. (2006) Comparison of evolutionary rates in the mitochondrial DNA cytochrome $b$ and control region and their implications for phylogeny of the Cobitoidea (Teleostei: Cypriniformes). Molecular Phylogenetics and Evolution, 39, 347-357.

Wiley, E.O. \& Mayden, R.L. (1985) Species and speciation in phylogenetic systematics, with examples from the North American fish fauna. Annals of the Missouri Botanical Garden, 72, 596-635.

Xia, X. (2000) Data analysis in molecular biology and evolution. Kluwer AcademicPublishers, Boston, 276 pp.

Xia, X. \& Xie, Z. (2001) DAMBE: Data analysis in molecular biology and evolution. Journal of Heredity, 92, 371-373.

Xiao, W.H., Zhang, Y.P. \& Liu, H.Z. (2001) Molecular Systematics of Xenocyprinae (Teleostei: Cyprinidae): Taxonomy, Biogeography, and Coevolution of a Special Group Restricted in East Asia. Molecular Phylogenetics and Evolution, 18, 163-173.

Yang, J.X., Chen, Y.R. \& Kottelat, M. (1994) Subspecific differentiation of Homatula variegatus with comments on its zoogeography. Zoological Research, 15, 58-67.

Zhou, W. \& He, J.C. (1993) Homatula distributed in Erhai area, Yunnan, China (Pisces: Cobitidae). Zoological Research, 14(1), 5-9.

Zhu, H.H. (1989) Environments and sediment action of fault lakes, Yunnan province. Chinese Academy of Sciences, Science press, Beijing, China, 109 pp.

Zhu, S.Q. (1989) The loaches of the subfamily Nemacheilinae in China (Cypriniformes: Cobitidae). Jiangsu Science \& Technology Publishing House, Nanjing, China, 150 pp. 